\title{
NEURAL NETWORK BERBASIS ALGORITMA GENETIKA UNTUK PREDIKSI KESEMPATAN KERJA
}

\author{
ST. Aminah Dinayati Ghani ${ }^{1}$, Purwanto $^{2}$, Catur Supriyanto ${ }^{3}$ \\ ${ }^{1}$ STMIK Dipanegara Makassar, ${ }^{2,3}$ Univeristas Dian Nuswantoro \\ *1amyudinus2016@gmail.com
}

Disetujui: Maret 2018. Dipublikasikan: April 2018

\begin{abstract}
ABSTRAK
Kesempatan kerja merupakan aspek kehidupan yang paling dibutuhkan dalam memenuhi kebutuhan hidup manusia. Oleh karena itu perlu diketahui faktor-faktor ekonomi apa saja yang mempengaruhi pertumbuhan kesempatan kerja dengan cara pengelolaan yang tepat untuk mengantisipasi kemungkinan buruk yang dapat mengganggu pertumbuhan kesempatan kerja. Tujuan dari penelitian ini adalah untuk mengetahui akurasi dari prediksi kesempatan kerja dengan menggunakan Neural Network dan pembobotan menggunakan Algoritma Genetika. Hasil penelitian menunjukkan bahwa akurasi yang didapatkan untuk prediksi kesempatan kerja menggunakan Algoritma Neural Network adalah sebesar 87,45 \% dengan AUC 0,89 termasuk dalam good classification, sedangkan apabila menggunakan Algoritma Neural Network berbasis Algoritma Genetika untuk pembobotan atribut maka nilai akurasi yang didapatkan adalah sebesar 88,30\% dan AUC 0,92 termasuk dalam excelent classification.
\end{abstract}

Kata kunci: Neural Network, Algoritma Genetika, Kesempatan Kerja.

\begin{abstract}
Employment is an aspect of life is most needed in meeting human needs. Therefore, please note the economic factors that influence the growth of employment by means of proper management to anticipate the possibility of bad that can interfere with the growth of employment. The purpose of this study was to determine the accuracy of the prediction of employment by using Neural Network and weighting using Genetic Algorithms. The results showed that the prediction accuracy is obtained for employment using Neural Network algorithm is equal to $87.45 \%$ with 0.89 AUC included in good classification.
\end{abstract}

Kata kunci: Neural Network, Algoritma Genetika, Kesempatan Kerja.

\section{PENDAHULUAN}

Dimensi masalah kesempatan kerja memang cukup rumit, bukan hanya sekedar keterbatasan lapangan pekerjaan atau peluang kerja serta rendahnya produktivitas namun jauh lebih serius dengan penyebab yang berbeda-beda. Pada dasawarsa yang lalu, masalah pokoknya tertumpu pada kegagalan penciptaan lapangan kerja yang baru pada tingkat yang sebanding dengan laju pertumbuhan output industri. Seiring dengan berubahnya lingkungan makro ekonomi mayoritas negara-negara berkembang, angka pengangguran yang meningkat pesat terutama disebabkan oleh "terbatasnya permintaan" tenaga kerja, yang selanjutnya semakin diciutkan oleh faktor-faktor eksternal seperti memburuknya kondisi neraca pembayaran, meningkatnya masalah utang luar negeri dan kebijakan lainnya, yang pada gilirannya telah mengakibatkan kemerosotan pertumbuhan industri, tingkat upah, dan akhirnya penyedian lapangan kerja (Todaro M.P. Smith, 2006).

Pengangguran adalah suatu kondisi di mana seseorang yang ingin bekerja dan 
mempunyai kemampuan dibidang masingmasing tetapi dikarenakan terbatasnya suatu pekerjaan yang tersedia dan tidak memadai bahkan bisa juga tidak tersedianya lapangan kerja. Permasalahan penggangguran merupakan permasalahan nasional yang telah lama dirasaakan oleh bangsa Indonesia. Berikut gambar.1 yang merupakakan grafik dari jumlah pengangguran di Indonesia dari tahun 2007 sampai dengan tahun 2013:

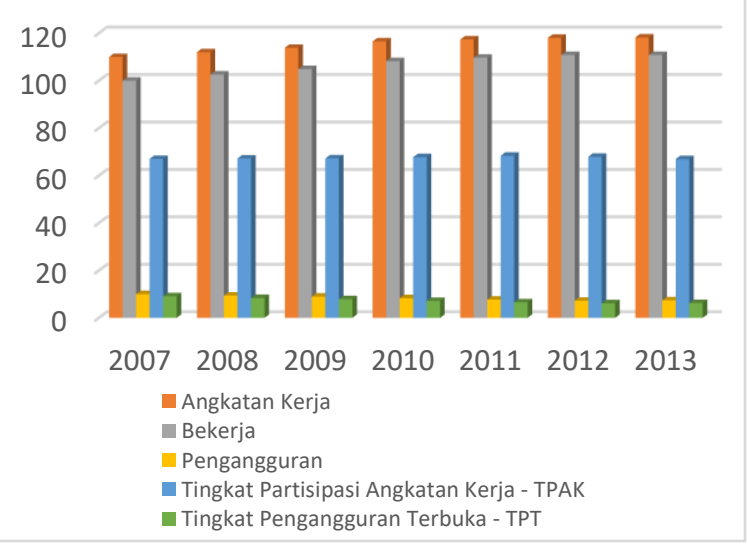

Gambar 1 Grafik Tingkat Penangguran di Indoesia

Grafik di atas memperlihatkan angka pengangguran di Indonesia dalam beberapa tahun terakhir menunjukkan penurunan yang terjadi secara perlahan dan berkelanjutan, Meskipun demikian masih menjadi masalah karena masih besarnya jumlah pengangguran. Data statistik terakhir dari Badan Pusat Statistik mengenai jumlah pengangguran pada bulan Februari 2016 adalah sebanyak 7,02 juta jiwa, angka yang amat besar karena banyaknya pengangguran ini bahkan mengalahkan jumlah populasi di beberapa provinsi di Indonesia. Untuk itu, cara yang paling utama untuk mengatasi pengangguran adalah melakukan perluasan kesempatan kerja. Perluasan kesempatan kerja sangat penting untuk tenaga kerja karena menyangkut pemenuhan kesejahteraan hidup.
Prediksi kesempatan kerja merupakan masalah yang menarik untuk diteliti. Riset bidang komputer untuk memprediksi kesempatan kerja perlu dilakukan dalam rangka mengetahui faktorfaktor yang berpengaruh pada prediksi kesempatan kerja seperti pengeluaran pemerintah, jumlah kredit serta upah minimum provinsi dalam suatu negara. Faktor yang mempengaruhi masalah yang terjadi disebabkan karena banyaknya indikator-indikator dari faktor-faktor yang berpengaruh pada kesempatan kerja. Oleh sebab itu, dibutuhkan sebuah metode untuk memprediksi faktor-faktor apa saja yang mempunyai pengaruh pada kesempatan kerja tersebut. Dengan menganalisa data yang ada menggunakan klasifikasi, maka diharapkan bisa didapatkan model prediksi yang akurat sesuai dengan yang telah terjadi. Hasil peramalan yang diperoleh dapat digunakan untuk mengetahui akurasinya.

Lee dan Choi S. (Lee and S. Choi, 2013) menyajikan investigasi kepailitan multi-industri termasuk konstruksi, ritel, dan manufaktur pada perusahaan di Korea dengan menggunakan jaringan syaraf backpropagation (BNN). Penelitian ini bermaksud untuk menunjukkan model spesifik industri untuk memprediksi kebangkrutan dengan memilih variabel independen yang sesuai. Hasil prediksi ini menunjukkan akurasi untuk BNN adalah 81,43\%, sedangkan akurasi dari Multiple Discriminant Analysis adalah sebesar 74,82 \% . Hasil prediksi menunjukkan bahwa $A N N$ lebih baik dari Multiple Discriminant Analysis di tiga industri. Hal ini menunjukkan bahwa penangkapan model jaringan saraf yang lebih baik untuk pola nonlinear antara variabel independen dan kebangkrutan dibandingkan dengan $M D A$.

(Shifei, Chunyang, dan Junzhao, 2011) menggunakan algoritma genetika untuk menghindari terjadinya stuck pada lokal minimum, dan memberikan hasil yang 
lebih stabil dengan cara menentukan bobot jaringan yang bisa beradaptasi pada setiap iterasi terhadap model arsitektur yang telah ditentukan secara manual. (Kim dan Kang, 2012) menyatakan bahwa algoritma genetika digunakan sebagai alat yang efektif untuk memecahkan suatu operasi pencarian lokal. Algoritma Genetika dapat mencegah optima lokal dengan menggunakan crossover dan mutasi operator. Penelitian ini mengusulkan sebuah teknik optimasi cakupan berbasis algoritma genetika untuk tujuan memecahkan masalah multi-collinearity. Hasil empiris dengan prediksi kebangkrutan pada perusahaan-perusahaan Korea menunjukkan bahwa optimasi algoritma genetika yang diusulkan dapat membantu untuk merancang beragam sistem klasifikasi yang sangat akurat.

Berdasarkan hal tersebut $\mathrm{di}$ atas sehingga peneliti tertarik untuk mengambil judul Neural Network berbasis Algoritma Genetika untuk Prediksi Kesempatan Kerja.

\section{METODE PENELITIAN}

Pada penelitian ini menggunakan 5 atribut bertipe numerikal, yaitu : Pengeluaran Pemerintah (x1), Jumlah Kredit (x2), Upah Minimum (x3), Investasi (x4) dan Pertumbuhan Ekonomi (x) dan labelnya yaitu kesempatan kerja (Y). Adapun desain Eksperimennya dapat dilihat pada gambar 5 di bawah ini :

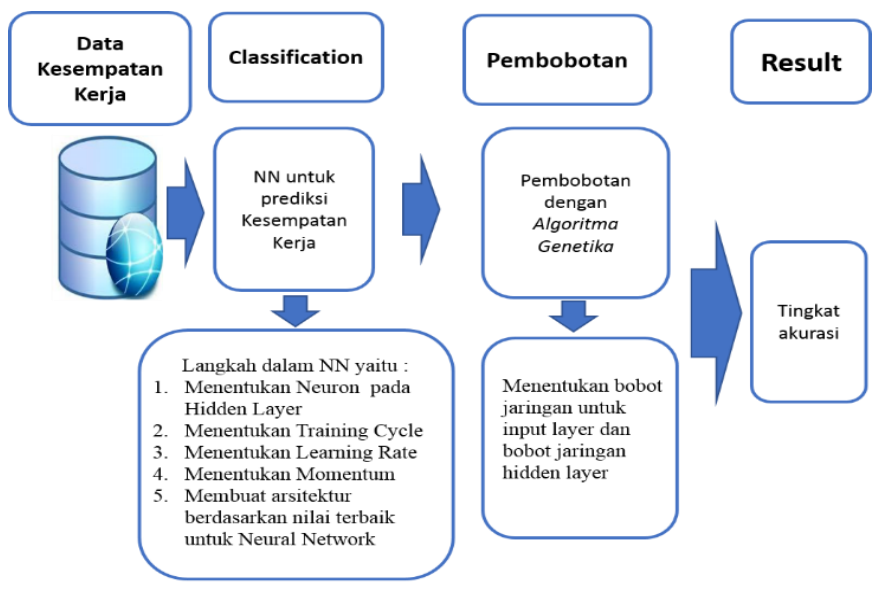

Gambar 2 Desain Eksperimen
Data preprocessing yang dilakukan adalah discreatization dan normalisasi data:

\section{Decreatization}

Discretization adalah data yang berupa numerik diubah menjadi data berbentuk nominal untuk label kesempatan kerja, yang dilakukan dengan menggunakan metode cut point yang mengacu pada nilai riil dalam kisaran nilai kontinyu dengan membagi rentang menjadi dua interval yang sama, satu interval kurang dari atau sama dengan cut point dan interval lainnya interval lebih besar dari cut point (Bramer, 2007).

$$
\text { cut point }=\frac{\max \text { value }-\min \text { value }}{2}
$$

\section{Normalisasi}

Normalisasi dibutuhkan sebelum proses data mining, agar tidak ada parameter yang mendominasi dalam perhitungan jarak antar data. Semua variabel akan dinormalisasi pada rentang 0 sampai dengan 1 (H. Liu, et al, 2002) dengan menggunakan persamaan pada rumus berikut ini:

$$
x^{\prime}=\frac{x-\min \text { value }}{\max \text { value }-\min \text { value }}
$$

Data didiscreatization dan dinormalisasi langkah selanjutnya yang dilakukan adalah dengan mencari model terbaik untuk aristektur dari Neural Network dengan cara menentukan Neuron pada Hidden Layer, menentukan Training Cycle, menentukan Learning Rate, menentukan Momentum.

Setelah mendapatkan arsitektur terbaik dari Neural Network kemudian melakukan pembobotan dengan menggunakan Algoritma Genetika jaringan hidden layer dan jaringan outputnya dengan harapan dapat meningkatkan akurasi dan $A U C$ pada prediksi kesempatan kerja. Adapun klasifikasi dari predikis kesempatan kerja yang akan dihasilkan adalah Berpegaruh besar dan berpengaruh kecil. 


\section{Klasifikasi}

Klasifikasi merupakan salah satu teknik dasar dalam bidang data mining. Teknik klasifikasi diperlukan untuk dapat melakukan pengenalan pola, prediksi nilai, hingga pengambilan keputusan. Dalam hal pengambilan keputusan, diperlukan sistem rekomendasi yang berperan dalam memberikan rekomendasi sejumlah item kepada user sehingga dapat membantu user dalam mengambil keputusan (R. Rismala, 2016). Algoritma klasifikasi yang telah banyak dipakai secara luas, yaitu, Neural Networks, Analisa Statistik, Algoritma Genetika, Rough sets, Support Vector Machine, Decision/classification trees, Memory based reasoning, Support vector Machines (SVM), dan Bayesian classifiers/ Nä̈ve Bayes classifiers Metode Rule Based, Klasifikasi data terdiri dari 2 langkah proses. Pertama adalah learning (fase training), di mana algoritma klasifikasi dibuat untuk menganalisa data training lalu direpresentasikan dalam bentuk rule klasifikasi. Proses kedua adalah klasifikasi, dimana data tes digunakan untuk memperkirakan akurasi dari rule klasifikasi (Han and Kamber, 2011).

\section{Kesempatan Kerja}

Kesempatan kerja adalah suatu keadaan di mana semua pekerja yang ingin bekerja pada suatu tingkat upah tertentu akan dengan mudah mendapatkan pekerjaan (Gorunescu, 2011). Pandangan lain tentang kesempatan kerja yang mengartikan kesempatan kerja sebagai lapangan pekerjaan yang sudah diisi (employment) dan lapangan pekerjaan yang masih lowong (vacancy). Dari lapangan pekerjaan yang masih lowong tersebut timbul kebutuhan tenaga kerja. Adanya kebutuhan tersebut berarti ada kesempatan kerja bagi orang yang menganggur. Dengan diisinya lapangan pekerjaan oleh para penganggur itu, maka berarti kesempatan kerja adalah lapangan pekerjaan yang sudah diduduki/diisi (Sukirno, 2010).

Berdasarkan berbagai pandangan mengenai kesempatan kerja tersebut, maka kesempatan kerja secara umum dapat diartikan sebagai suatu keadaan yang mencerminkan jumlah dari total angkatan kerja yang dapat diserap atau ikut secara aktif dalam kegiatan perekonomian. kesempatan kerja dapat dibedakan menjadi dua kategori yaitu kesempatan kerja permanen yaitu kesempatan kerja yang memungkinkan orang bekerja secara terus menerus sampai mereka pensiun atau tidak mampu lagi untuk bekerja. Kategori lainnya adalah kesempatan kerja temporer, yaitu kesempatan kerja yang memungkinkan seseorang bekerja dalam waktu yang relatif singkat, kemudian kembali menganggur untuk menunggu Kesempatan Kerja baru berikutnya.

Adapun beberapa faktor yang mempengaruhi kesempatan kerja tersebut adalah : (1) Pengeluaran Pemerintah: Secara teoritik dalam APBN, Pengeluaran Pemerintah (Government Expenditure) diarahkan untuk dua tujuan utama, yaitu pertama, pengeluaran untuk menjalankan mesin birokrasi atau roda pemerintahan dan kedua, pengeluaran untuk merangsang atau menggerakkan kegiatan ekonomi secara umum. (2) Jumlah Kredit: (Bastian, 2006) mendefinisikan kredit adalah peminjaman uang atau tagihan yang dapat dipersamakan dengan itu berdasarkan persetujuan atau kesepakatan pinjam meminjam antara bank dan pihak lain yang mewajibkan pihak meminjam untuk melunasi utangnya setelah jangka waktu tertentu dengan jumlah bunga, imbalan atau pembagian hasil keuntungan. (3) Upah Minimum: Berdasarkan kebijakan upah 
minimum Indonesia Upah adalah hak pekerja/buruh yang diterima dan dinyatakan dalam bentuk uang sebagai imbalan dari pengusaha atau pemberi kerja kepada pekerja/buruh yang ditetapkan dan dibayarkan menurut suatu perjanjian kerja, kesepakatan, atau peraturan perundangundangan, termasuk tunjangan bagi pekerja/buruh dan keluarganya atas suatu pekerjaan dan/atau jasa yang telah atau akan dilakukan. (4) Investasi: Investasi didefinisikan sebagai pembentukan modal tetap domestic (domestic fixed capital formation) yang kemudian membedakan Investasi atas Innvestasi Bruto dan Investasi(suindayah). (Mankiw, 2007) membagi Investasi kedalam tiga kategori; Investasi Tetap Bisnis, Investasi Residensial dan Investasi Persediaan. Investasi Tetap Bisnis (Business Fixed Investment) melingkupi pembelian peralatan peralatan untuk proses produksi. Investasi Residensial (Residential Investment) mencakup pembelian rumah baru baik untuk ditinggali maupun untuk dipersewakan. Sedangkan Investasi Persediaan (Inventory Investment) meliputi barang barang termasuk barang jadi dan setengah jadi serta bahan bahan dan perlengkapan yang ditempatkan digudang oleh perusahaan. (5) Pertumbuhan Ekonomi: Pertumbuhan ekonomi diartikan sebagai perkembangan kegiatan dalam perekonomian yang menyebabkan barang dan jasa yang diproduksi dalam masyarakat bertambah dan kemakmuran masyarakat meningkat (Gorunescu, 2011). Jadi pertumbuhan ekonomi mengukur prestasi dari perkembangan suatu perekonomian. Disamping itu, tenaga kerja bertambah sebagai akibat perkembangan pertumbuhan penduduk.

\section{Artificial Neural Network}

Artificial Neural Network (ANN) atau biasa disebut dengan Jaringan Saraf Tiruan (JST) merupakan sebuah sistem jaringan yang modelnya berdasarkan pada sistem jaringan saraf manusia. Tujuan dibuatnya Neural Network adalah untuk membuat sebuah sistem yang mampu belajar sendiri sesuai dengan kondisi lingkungan dan data yang kita berikan serta dapat dimodelkan data secara statistic non linier, pemodelan yang kompleks tersebut dapat menghubungkan antara input dan output agar menemukan pola-pola data seperti curve fitting (Utomo, 2015).

Artificial Neural Network (ANN) merupakan konsep dari rekayasa pengetahuan dalam bidang kecerdasan buatan yang dirancang dengan mengadopsi sistem saraf manusia, yang pemrosesan utamanya terdapat di otak. Bagian terkecil dari otak manusia adalah sel saraf yang disebut unit dasar proses informasi atau neuron. Ada sekitar 10 miliar neuron dalam otak manusia dan sekitar 60 tereliun koneksi (sinaps/synapse) antar neuron dalam otak manusia. Dengan menggunakan neuronneuron tersebut secara simultan, otak manusia dapat memproses informasi secara paralel dan cepat (Utomo, 2015).

Artificial Neural Networks (ANN), dikenal juga dengan istilah multilayer perceptron, memiliki bentuk umum sebagai berikut [16]:

$$
y_{k}(x, w)=\sigma\left(\sum_{j=1}^{M} w_{k j}^{(2)} h\left(\sum_{i=1}^{D} w_{j i}^{(1)} x_{i}+w_{j 0}^{(1)}\right)+w_{k 0}^{(2)}\right)
$$

dimana :

$\mathrm{w}_{\mathrm{kj}}, \mathrm{w}_{\mathrm{ji}} \mathrm{a}:$ parameter bobot

$\mathrm{W}_{\mathrm{k} 0}, \mathrm{~W}_{\mathrm{j} 0} \quad$ : parameter bias

$h(),. \sigma($.$) \quad : fungsi aktivasi$

sehingga secara sederhana ANN adalah suatu fungsi non linear dari suatu himpunan variabel input $\left\{\mathrm{x}_{\mathrm{i}}\right\}$ ke himpunan variabel 
output $\left\{\mathrm{y}_{\mathrm{k}}\right\}$ yang dikontrol oleh parameter bobot dan bias (Eko P., 2014).

Beberapa permasalahan yang dapat diselesaikan dengan ANN adalah prediksi, klasifikasi, optimasi dan pengenalan pola. Berdasarkan kemampuan yang dimiliki, hasil dari pembelajaran Artificial Neural Network dapat digunakan untuk menemukan solusi dari suatu permasalahan. Di bawah ini adalah struktur ANN (Bishop, 1999).

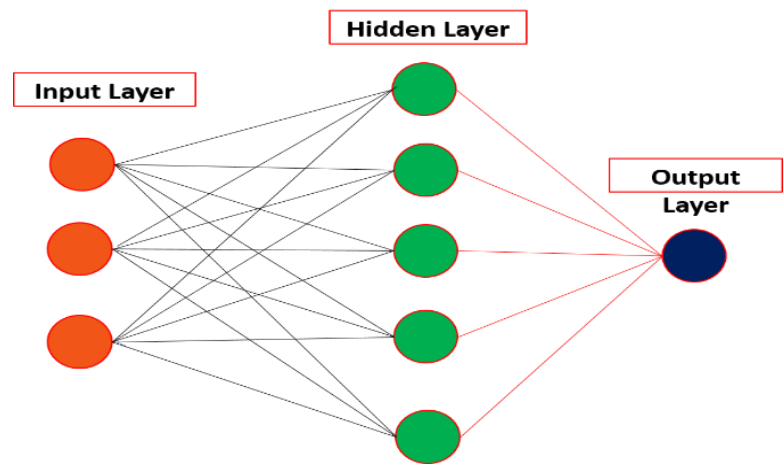

Gambar 3. Desain Umum Artificial Neural Network

Backpropagation juga merupakan bagian dari model Neural Network yang paling populer serta dapat melakukan suatu pembelajaran untuk prediksi pada data mining (Utomo, 2015). Algoritma Backpropagation merupakan bagian dari algoritma supervised (pembelajaran terawasi) yang sering dipakai oleh perceptron dengan banyak lapisan untuk merubah bobot-bobot yang terhubung dengan neuron-neuron yang ada pada lapisan tersembunyi. Algoritma ini menggunakan error keluaran untuk mengubah nilai bobotbobotnya dalam arah mundur (backward). Untuk mendapatkan error ini tahap perambatan maju (forward propagation) harus dikerjakan terlebih dahulu (Apriliyah, et al).

\section{Algoritma Genetika}

Algoritma Genetika (AG) adalah algoritma pencarian yang berdasarkan pada mekanisme seleksi alamiah dan genetika alamiah. Pada awalnya algoritma genetika digunakan untuk algoritma pencarian parameter-parameter optimal. Namun seiring dengan perkembangannya, algoritma genetika dapat diaplikasikan untuk berbagai masalah lain misalnya untuk pembelajaran, pemrograman otomatis, peramalan,dan lain sebagainya. Dalam bidang soft computing, algoritma genetika telah banyak digunakan untuk mendapatkan nilai-nilai parameter yang optimal untuk jaringan syaraf tiruan maupun utase fuzzy (Yanti, 2011).

Untuk memeriksa hasil optimasi, kita membutuhkan fungsi fitness, yang menandakan gambaran hasil (solusi) yang sudah dikodekan. Selama berjalan induk harus digunakan untuk reproduksi, pindah silang dan utase untuk menciptakan keturunan. Jika Algoritma Genetika didesain secara baik, populasi akan mengalami konvergensi dan akan didapatkan sebuah solusi yang optimum (Yanti, 2011).

Terdapat beberapa komponen dalam algoritma genetika, yaitu (Suyanto, 2011) seperti gambar di bawah ini:

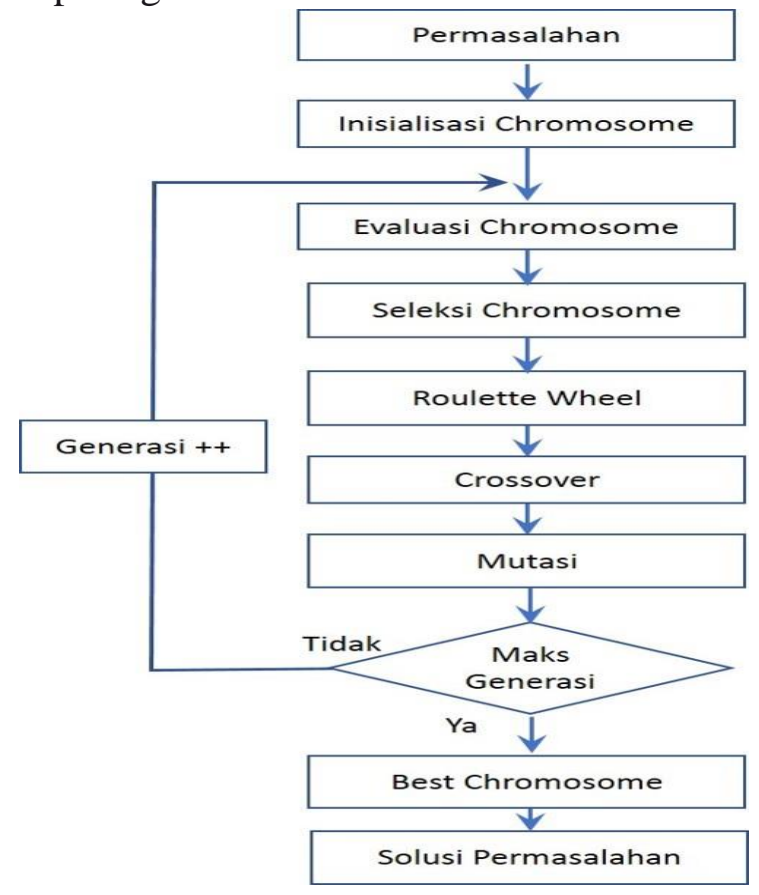

Gambar 4. Alur Kerja Algoritma Genetika 


\section{Confusion Matrix dan AUC}

Confusion Matrix merupakan data set yang hanya memiliki dua kelas, yaitu kelas yang satu sebagai positif dan kelas yang lain sebagai negatif. Confusion Matrix terdiri dari dari empat sel yaitu True Possitives (TP), False Possitives (FP, True Negatives (TN) dan False Negatives (FT) (Zamani dan Amaliah, 2012).

AUC (Area Under Curve) mengukur kinerja diskriminatif dengan memperkirakan probabilitas output dari sampel yang dipilih secara acak dari populasi positif atau negatif, semakin besar AUC (Area Under Curve) maka semakin kuat klasifikasi yang digunakan karena AUC (Area Under Curve) merupakan bagian dari daerah unit persegi. Nilai dari $A U C$ adalah antara $0,0-1,0$. Nilai $A U C$ dapat dibagi menjadi beberapa kelompok yaitu :
a. $0.90-1.00=$ Excelent Classification
b. $0.80-0.90=$ Good Classification
c. $0.70-0.80=$ Fair Classification
d. $0.60-0.70=$ Poor Classification
e. $0.50-0.60=$ Failure

\section{HASIL DAN PEMBAHASAN}

Pada percobaan pertama penulis menggunakan algoritma Neural Network terlebih dahulu tanpa menggunakan Algoritma genetika untuk optimasi.

Percobaan tersebut menggunakan 231 data dan 5 atribut prediktor yang sudah dinormalisasi menjadi data numerik terlebih dahulu. Percobaan tersebut dilakukan beberapa kali untuk mendaptkan arsitektur dari Neural Network dengan mengubah nilai dari jumlah Neuron pada Hidden Layer, Training Cycle, Learning Rate dan Momentum sehingga dihasilkan nilai terbaik untuk masing-masing seperit tampak pada tabel 1 di bawah ini :
Tabel 1. Nilai Terbaik untuk Neural Network

\begin{tabular}{cccccc}
\hline $\begin{array}{c}\text { Neur } \\
\text { on }\end{array}$ & $\begin{array}{c}\text { Traini } \\
\text { ng } \\
\text { Cycle }\end{array}$ & $\begin{array}{c}\text { Learni } \\
\text { Rate } \\
\text { Rate }\end{array}$ & $\begin{array}{c}\text { Mome } \\
\text { n }\end{array}$ & $\begin{array}{c}\text { Akura } \\
\text { si }\end{array}$ & AUC \\
\hline 10 & 500 & 0,3 & 0,2 & 86,14 & 0,883 \\
10 & 500 & 0,3 & 0,3 & 85,71 & 0,880 \\
10 & 500 & 0,3 & 0,4 & 83,97 & 0,879 \\
10 & 500 & 0,3 & 0,5 & 83,97 & 0,884 \\
10 & 500 & 0,3 & 0,6 & 85,27 & 0,882 \\
10 & 500 & 0,3 & 0,7 & 86,58 & 0,889 \\
10 & 500 & 0,3 & 0,8 & 87,45 & 0,890 \\
10 & 500 & 0,3 & 0,9 & 85,27 & 0,896 \\
\hline
\end{tabular}

Berdasarkan hasil percobaan di atas untuk mencari model terbaik pada arsitektur neural network adalah yaitu neuron hidden layer 10 , training cycle 500, learning rate 0,3 dan momentum 0,8 dapat dilihat akurasi dan $A U C$ untuk prediksi kesempatan kerja dengan menggunakan tools RapidMiner seperti pada tabel 2 di bawah ini:

Tabel 2. Akurasi Neural Network

\begin{tabular}{|c|c|c|c|}
\hline \multicolumn{4}{|c|}{ Accuracy: $87.45 \%+/-5.98 \%$ (mikro: $87.45 \%$ ) } \\
\hline & True Kecil & $\begin{array}{l}\text { True } \\
\text { besar }\end{array}$ & $\begin{array}{c}\text { Class } \\
\text { precision }\end{array}$ \\
\hline $\begin{array}{l}\text { Prediksi } \\
\text { Kecil }\end{array}$ & 100 & 13 & $88.50 \%$ \\
\hline $\begin{array}{c}\text { Prediksi } \\
\text { Besar }\end{array}$ & 16 & 102 & $86.44 \%$ \\
\hline $\begin{array}{l}\text { Class } \\
\text { recall }\end{array}$ & $86.21 \%$ & $88.70 \%$ & \\
\hline
\end{tabular}

Akurasi yaitu proporsi jumlah prediksi nilai yang benar, yaitu:

$$
\begin{aligned}
\text { Akurasi } & =\frac{\mathrm{TP}+\mathrm{TN}}{\mathrm{TP}+\mathrm{FN}+\mathrm{FP}+\mathrm{TN}} \\
\text { Akurasi } & =\frac{100+102}{100+102+16+13} \\
& =87,45 \%
\end{aligned}
$$

Berdasarkan tabel 2 di atas maka dapat dilihat bahwa akurasi untuk prediksi 
kesempatan kerja dengan menggunakan metode Neural Network adalah sebesar 87, $45 \%$, sedangkan AUC (Area Under Curve) ditampilkan dalam bentuk grafik pada gambar 6 di bawah ini dengan nilai $A U C$ sebesar 0,890 termasuk dalam good classification.

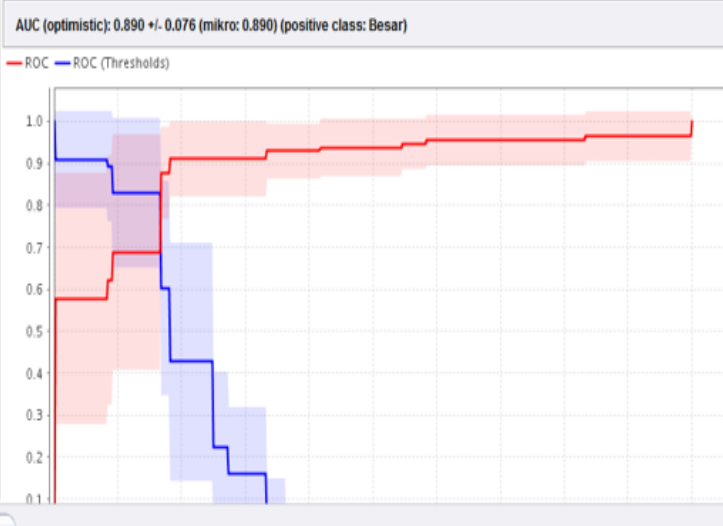

Gambar 5. AUC Prediksi Kesempatan Kerja dengan Metode

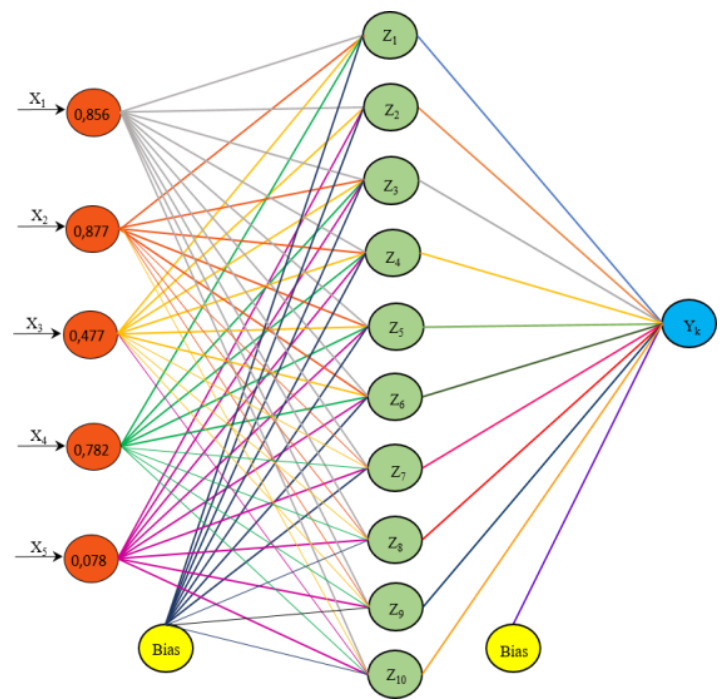

Gambar 6. Model Arsitektur Neural Network

Adapun nilai bobot yang didapatkan dengan menggunakan tools RapidMiner untuk optimasi menggunkn Algritma Genetika adalah seperti yang ditampilkan pada tabel 3 di bawah ini :

Tabel 3: Bobot Atribut Algoritma Genetika

Attibute Weight (Bobot)

\begin{tabular}{ll}
\hline Pengeluaran Pemerintah (x1) & 1 \\
Jumlah Kredit (x2) & 1
\end{tabular}

\begin{tabular}{ll} 
Upah Minimum (x3) & 1 \\
Investasi (x4) & 1 \\
Pertumbuhan Ekonomi (x5) & 1 \\
\hline
\end{tabular}

Berdasarkan hasil experimen yang sudah dilakukan menggunakan Neural Network dan dioptimasi menggunakan Algoritma Genetika didapatkan hasil akurasi dan AUC terbaik seperti pada tabel 4 sebagai berikut :

Tabel 4. Akurasi Neural Network dan Algoritma

\begin{tabular}{cccc}
\multicolumn{4}{c}{ Genetika } \\
\hline $\begin{array}{c}\text { Accuracy: } \\
\text { (mikro:82.00\%) }\end{array}$ & $\mathbf{8 8 . 3 0 \%}$ & $+/-$ & $14.00 \%$ \\
\hline & $\begin{array}{c}\text { True } \\
\text { Kecil }\end{array}$ & $\begin{array}{c}\text { True } \\
\text { besar }\end{array}$ & $\begin{array}{c}\text { Class } \\
\text { precision }\end{array}$ \\
\hline $\begin{array}{c}\text { Prediksi } \\
\text { Kecil }\end{array}$ & 102 & 13 & $90.91 \%$ \\
$\begin{array}{c}\text { Prediksi } \\
\text { Besar } \\
\text { Class } \\
\text { recall }\end{array}$ & 14 & 102 & $85.76 \%$ \\
\hline
\end{tabular}

$$
\begin{aligned}
\text { Akurasi } & =\frac{\mathrm{TP}+\mathrm{TN}}{\mathrm{TP}+\mathrm{FN}+\mathrm{FP}+\mathrm{TN}} \\
\text { Akurasi } & =\frac{102+102}{102+102+14+13} \\
& =88,30 \%
\end{aligned}
$$

Berdasarkan tabel 4 di atas maka dapat dilihat bahwa akurasi untuk prediksi kesempatan kerja dengan menggunakan metode Neural Network berbasis Algoritma Genetika adalah sebesar 88,30 \% sedangkan untuk AUC (Area Under Curve) ditampilkan grafik pada gambar 8 di bawah ini dengan nilai $A U C$ sebesar 0,921 masuk dalam excelent classification.

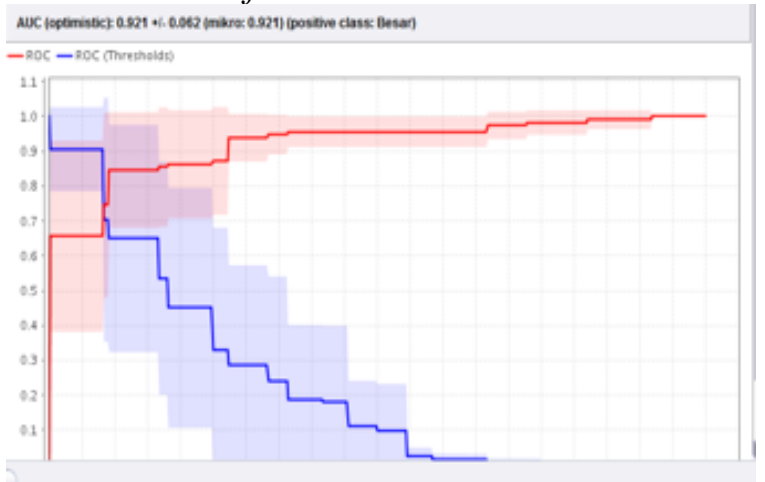

Gambar 7. AUC Prediksi Kesempatan Kerja dengan Neural Network berbasis GA 
Berdasarkan hasil eksperimen di atas dengan menggunakan confusion matrix dan AUC dapat dilihat bahwa hasil pengujian dengan metode Neural Network berbasis Algoritma Genetika memiliki nilai akurasi lebih tinggi dibandingkan dengan menggunakan metode Neural Network tanpa menggunakan optimasi Algoritma Genetika.

Nilai akurasi yang didapatkan dengan metode Neural Network adalah $87,45 \%$ dan AUC 0,890 dengan nilai diagnosa good classification, sedangkan untuk nilai akurasi dengan menggunakan Neural Network berbasis Algoritma Genetika sebesar 88,30\% dan AUC 0,920 dengan nilai diagnosa excelent classification.

Hasil akurasi dengan menggunakan Neural Network berbasis Algoritma genetika lebih tinggi 0,85\% dibandingkan bila hanya menggunakan metode Neural Network saja.

Berdasarkan hal tersebut maka dapat disimpulkan bahwa penggunaan optimasi Algoritma Genetika dapat meningkatkan akurasi dari metode Neural Network saja untuk prediksi kesempatan kerja.

Untuk lebih jelasnya dapat di lihat pada gambar 4.7. dan gambar 9 dan 10 di bawah ini:

Perbandingan Akurasi NN dan Akurasi NN + GA

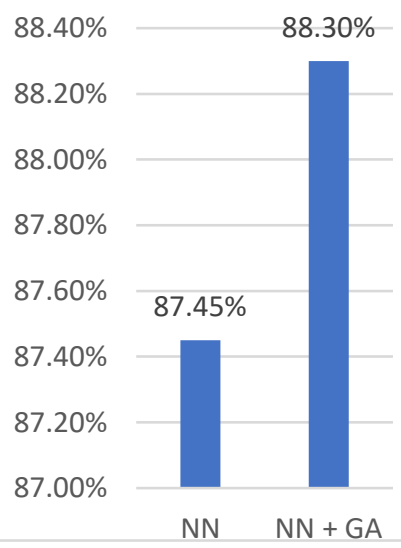

Gambar 8. Grafik Perbandingan Akurasi
Perbandingan AUC NN dan AUC NN + GA

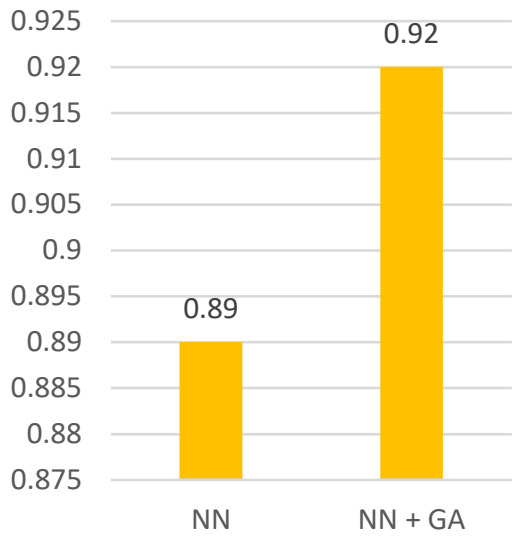

Gambar 9. Grafik Perbandingan AUC

\section{PENUTUP}

Klasifikasi Hasil dari eksperimen yang telah dilakukan pada penelitian ini dapat disimpulkan sebagai berikut : (1) Hasil evaluasi yang sudah dilakukan menggunakan metode Neural Network untuk prediksi kesempatan menghasilkan nilai akurasi sebesar 87,45 \% dengan AUC 0,890 dengan nilai diagnosa Good Classification. (2) Hasil evaluasi yang sudah dilakukan menggunakan metode Neural Network yang dioptimasi menggunakan Algoritma Genetika memberikan nilai akurasi $88,30 \%$ dan $A U C$ 0,920 dengan nilai diagnosa excellent classification yang lebih tinggi untuk prediksi kesempatan kerja. Berdasarkan hal tersebut di atas maka dapat ditarik kesimpulan bahwa dengan menggunakan optimasi Algoritma Genetika akan meningkatkan akurasi sebesar 0,85 \% dibandingkan bila hanya menggunakan metode Neural Network saja demikian pula dengan nilai untuk AUC meningkat sebesar 0,03 lebih baik daripada hanya dengan menggunakan metode Neural Network saja untuk prediksi Kesempatan Kerja. 


\section{DAFTAR PUSTAKA}

Todaro M.P. Smith, Pembangunan Ekonomi (Edisi Kesembilan). (Drs. Haris Munandar, MA dan Puji A.L., SE, Pentj). Jakarta: Gelora Aksara Pratama, 2006

S. Lee and W. S. Choi, "A multi-industry bankruptcy prediction model using back-propagation neural network and multivariate discriminant analysis," Expert Syst. Appl., vol. 40, no. 8, pp. 2941-2946, 2013.

S. Ding, C. Su, and J. Yu, "An optimizing BP neural network algorithm based on genetic algorithm," Artif. Intell. Rev., vol. 36, no. 2, pp. 153-162, 2011.

M. J. Kim and D. K. Kang, "Classifiers selection in ensembles using genetic algorithms for bankruptcy prediction," Expert Syst. Appl., vol. 39, no. 10, pp. 9308-9314, 2012.

M. Ridwan, H. Suyono, and M. Sarosa, "Penerapan Data Mining Untuk Evaluasi Kinerja Akademik Mahasiswa Menggunakan Algoritma Naive Bayes Classifier," Eeccis, vol. 7, no. 1, pp. 59-64, 2013.

D. C. P. Buani, "Optimasi Algoritma Naïve Bayes dengan Menggunakan Algoritma Genetika untuk Prediksi Kesuburan (Fertility)," vol. 4, 2016.

R. Rismala, "Penerapan Teknik Klasifikasi pada Sistem Rekomendasi Menggunakan Algortima Genetika," vol. II, no. 3, 2016.

J. H. dan M. Kamber, "Data Mining: Concepts, Models, and Techniques," dalam Springer, Verlag Berlin Heidelberg.," 2011.
F. Gorunescu, "Data Mining: Concept, Models and Tsechniques.pdf." Springer, 2011.

S. Sukirno, Ekonomi Pembangunan (Edisi Kedua). jakarta: KENCANA Prenada Media Group, 2010.

Hakim Abdul, "Ekonomi Pembangunan (Cetakan Kedua).," 2004.

Bastian, "Akuntansi Perbankan, Edisi Pertama," vol. edisi Pert, 2006.

G. N. Mankiw, Principles of Economocs, ??? Edi. Cengage Learning Asia Pte Ltd., 2007.

W. Utomo, "Prediksi Nilai Ujian Nasional Produktif Sekolah Menengah Kejuruan Menggunakan Metode Neural Network," vol. 14, no. 1, pp. 33-41, 2015.

Prasetyo Eko, Data Mining Mengolah Data Menjadi Informasi Menggunakan Matlab, Aldo Sahala, Ed. Yogyakarta: CV. Andi Offset, 2014.

Bishop, "Neural Networks," Pattern Recognit., 1999.

Apriliyah and A. W. W. M, Wayan Firdaus, "Perkiraan Penjualan Beban Listrik Menggunakan Jaringan Syaraf Tiruan Resilent Backpropogation (RPROP)," vol. 4, no. 32, pp. 14-21, 2008.

N. Yanti, "Penerapan Metode Neural Network Dengan Struktur Backpropagation Untuk Prediksi Stok Obat Di Apotek(Studi Kasus : Apotek Abc)," Snati, vol. 2011, no. Snati, pp. C15-C20, 2011.

Suyanto, Algoritma Genetika. Yogyakarta: C.V Andi Offset, 2011.

A. M. Zamani and B. Amaliah, "Implementasi Algoritma Genetika 
pada Struktur Backpropagation Neural Network untuk Klasifikasi Kanker Payudara," J. Tek. POMITS, vol. 1, no. 1, pp. 1-6, 2012.

M. Bramer, "Principles of Data Mining, ser. Undergraduate Topics in Computer Science," Vasa, pp. 221-238, 2007.
H. Liu, F. Hussain, C. L. Tan, and M. Dash, "Discretization: An enabling technique," Data Min. Knowl. Discov., vol. 6, no. 4, pp. 393-423, 2002. 